\title{
フラップ手術時の歯周ポケットに関する研究
}

浅見浩之神田隆行長谷川明

日本歯科大学新潟歯学部歯周治療学教室

(主任：長谷川明教授)

(平成 4 年 12 月 14 日受付)

\section{A Study on Probing Depth of Periodontal Pockets Treated by Flap Surgery}

\author{
Hiroyuki ASAMI, Takayuki KANDA and Akira HASEGAWA \\ Department of Periodontics, The Nippon Dental University, School of Dentistry at Niigata \\ 1-8 Hamaura-cho, Niigata 951, Japan \\ (Chief : Prof. Akira HASEGAWA)
}

\begin{abstract}
Depth of periodontal pockets was recorded using eight standard measurements (distal, distofacial, facial, mesiofacial, mesial, distoligual, lingual and mesiolingual) and investigated at the time of flap surgery, and 6 and 12 months postoperatively. A total of 3080 surfaces of 385 teeth from 143 cases was studied at flap surgery, and 40 cases at 6 months and 50 cases at 12 months after operation. Depth of periodontal pockets at flap surgery was $3.8 \pm 2.0 \mathrm{~mm}$ and deeper pockets remained in the maxillary and molar areas. Depth of periodontal pockets at 6 months was $2.0 \mathrm{~mm} \pm 1.0 \mathrm{~mm}$, half of
\end{abstract}

that at flap surgery. Depth of periodontal pockets was improved $1.9 \pm 1.7 \mathrm{~mm}$ and $82.6 \%$ improved by more than $1 \mathrm{~mm}$. Depth of periodontal pockets at 12 months after operation was $2.2 \pm 1.1 \mathrm{~mm}$, deeper than at 6 months. Depth of periodontal pockets was improved $1.5 \pm 1.9 \mathrm{~mm}$ and $68.2 \%$ improved by more than $1 \mathrm{~mm}$. Depth of periodontal pockets at 12 months after operation had a tendency of recur. Depth of periodontal pockets on the apically positioned flap improved more than that of the modified widman flap, both 6 and 12 months after operation.

Key words : Flap surgery, Periodontal pocket, Measurement of interdental pocket, Modified Widman flap, Apically positioned flap

要旨：フラップ手術を受けた 143 症例, 385 歯, 3080 歯面を研究対象とし, さらにこの中から, 手術後 6 カ月 の 40 症例, 12 力月の 50 症例を追跡対象とし, 手術時, 手術後 6 力月, 手術後 12 力月の歯周ポケットの変化を 近遠心中央部を加えた 8 点法によって検索した結果, 以下の結論を得た。1. 手術時における歯周ポケットの深さ は, $3.8 \pm 2.0 \mathrm{~mm}$ であり，上顎において，また大臼歯部において深い歯周ポケットが存在していた。2. 手術後 6 力月の歯周ポケットの深さは, $2.0 \pm 1.0 \mathrm{~mm}$ で手術時のほぼ半分の值であり, 6 力月後の平均改善値は $1.9 \pm$ $1.7 \mathrm{~mm}$ で $82.6 \%$ にいて $1 \mathrm{~mm}$ 以上の改善をみた。3. 手術後 12 力月の歯周ポケットの深さは, $2.2 \pm 1.1 \mathrm{~mm}$ で手術後 6 力月の值より上昇した。12 カ月の平均改善値は, $1.5 \pm 1.9 \mathrm{~mm}$ で $68.2 \%$ において $1 \mathrm{~mm}$ 以上の改善 をみ, 手術後 6 カ月に比べると再発傾向にあった。4.Widman 改良法に準じたフラップ手術と歯肉弁根尖側移動 手術に準じたフラップ手術では, 手術後 6 カ月, 12 カ月ともに, 後者の方が高い改善值を示した。

索引用語 : フラップ手術, 歯周ポケット, 歯間部歯周ポケット測定, ウィドマン改良法, 歯肉弁根尖側移動手術

本論文の要旨は, 第 34 回秋季日本歯周病学会総会（1991 年 9 月 19 日）において発表した。 


\section{緒言}

歯周ポケット診查は歯周治療の臨床において重要で あり, 歯周疾患の病態の把握, 治療方針の樹立, 治療 効果の確認，さらにメイテナンスがうまくいっている かどうかなどを知る上で不可欠な事項である。

歯周ポケットに関する研究は, 測定法に関するも の，初診時の状態に関するものおよびその变化に関す るもの，治療法別にその推移をみたものなどがある が，歯周外科手術なかでも最も歯周ポケットに関係す るフラップ手術を中心に研究したものはない。

どの程度の深さの歯周ポケットがフラップ手術の対 象になり，またそれらは，日時の経過とともにどのよ うに変化していくのかを知ることは日常の臨床におい て興味のあるところである。

そこで，フラップ手術を行う直前に歯間部歯周ポ ケット測定用をそなえた歯周ポケット測定器で, 一般 に行われている個々の歯の煩側遠心, 煩側中央, 煩側 近心および舌側遠心, 舌側中央, 舌側近心の 6 点を計 測する 6 点法に加え, 近心部, 遠心部の隣接面コンタ クトポイント直下を測定する 8 点法によって, 上下顎 歯別, 前歯, 大小臼歯別, 歯面別にフラップ手術の対 象となる歯周ポケットの状態について詳細に検討し た。そして, 手術後 6 力月における歯周ポケットの変 化, また, 手術後 12 カ月における歯周ポケットの変 化を比較検討し, ぞの部位にどの程度の再発傾向があ るかを分析した。さらに現在, 世界的にも一般的に行 われているフラップ手術の手技別，すなわち Widman 改良法に準じたフラップ手術と歯肉弁根尖 側移動手術に準じたフラップ手術では, どのような歯 周ポケットの推移を示すのかについても検索した。

\section{材料と方法}

日本歯科大学新潟歯学部附属病院歯周治療科におい て，平成 2 年 1 月から 12 月までの 1 年間にフラップ 手術を受けた 143 症例, 385 歯, 3080 歯面を研究対象 とした。平均年齢は 48.5 歳, 男女比は男性 88 名, 女 性 55 名であった。さらにこの中から, 手術後 6 力月 の 40 症例, 12 力月の 50 症例を追跡対象とした。

以上の研究対象に対し, 手術時, 手術後 6 力月, 手 術後 12 力月に歯周ポケットの測定をした。

歯周ポケットの測定には, 日本歯科大学新潟歯学部
式の歯周ポケット測定器を使用した（図 1)。これは,

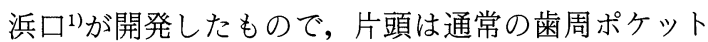
測定用，他の片頭は，歯間部歯周ポケット測定用と なっている。双方とも先端は $0.5 \mathrm{~mm}$ の球状であり, 3-2-2-2-2 mm の目盛があるが（図 2)，歯間部測定 用では，目盛部を 30 度に傾斜（後述）させた時に発 生する誤差を補正する目的で，3.45-2.30-2.30-2.30$2.30 \mathrm{~mm}$ の実長がある。

歯周ポケット測定器の目盛部と接続部と傾斜角度 は，通常の歯周ポケット測定用では，90 度，また， 歯間部測定用では 120 度になっている。これにより, 歯周ポケットの接続部を歯軸と垂直にたもてば，測定 器の目盛部が，通常の歯周ポケット測定用では歯軸と 平行に，また，歯間部測定用では，歯軸に対し 30 度 傾斜して位置することができる（図 3 )。

歯周ポケットの測定方法としては，1歯に対し，通 常の歯周ポケット測定用を使用し，測定器の目盛部を 歯軸と平行に使用した lineangle probingにより，唇 （煩）側近心隅角部（以下 $\mathrm{MB}$ と略す), 唇（煩）側 中央部 (以下 $\mathrm{B}$ と略す), 唇（頓）側遠心隅角部（以 下 DB と略す), 舌 (口蓋) 側近心隅角部（以下 ML と略す), 舌 (口蓋) 側中央部（以下 L と略す), 舌

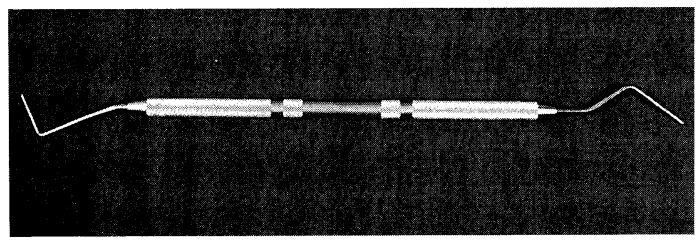

図 1 日本歯科大学新潟歯学部式歯周ポケット 測定器

（右側は歯間部歯周ポケット測定用）

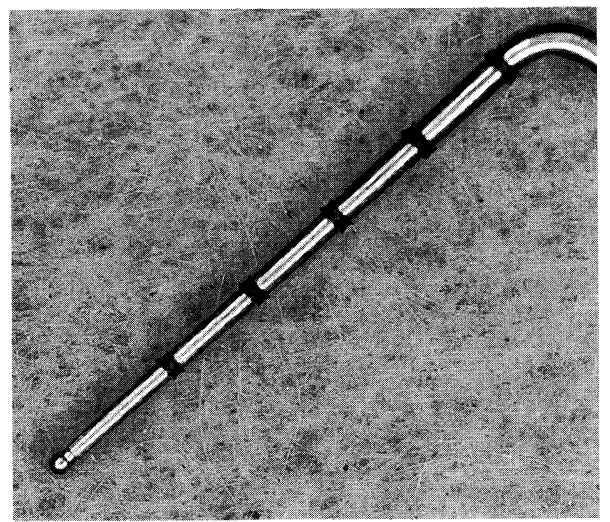

図 2 先端の形状 


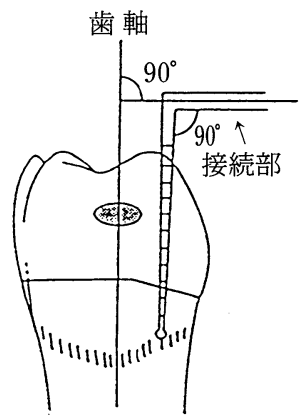

(Line-angle probing)

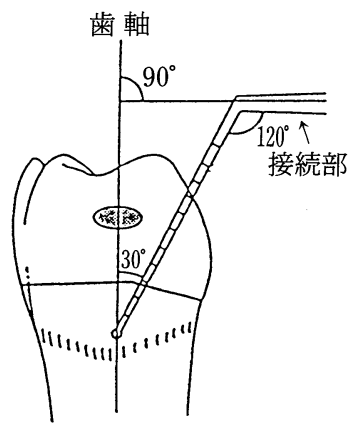

歯間部用プローブ

(Angled probing)

図 3 歯周ポケット測定器と測定方法

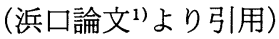

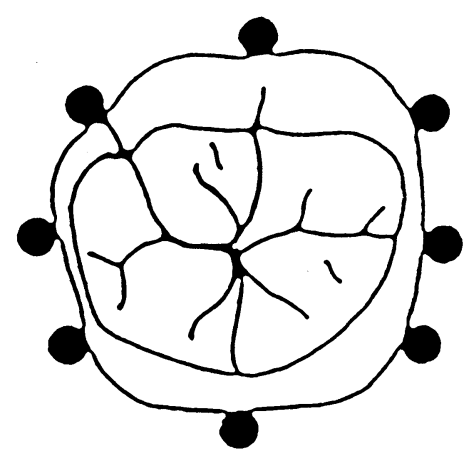

図 48 点計測法（浜口論文 ${ }^{1)}$ より引用）

（口蓋）側遠心隅角部（以下 DL と略す）の 6 点と歯 間部測定用を使用し, 測定器目盛部を唇 (煩) 側か ら, 30 度歯軸に傾斜させ挿入した angled probing に より, 遠心中央部 (以下 D と略す), 近心中央部 (以 下M と略す）の 2 点の計 8 点を計測した（図 4 ）。歯 周ポケット測定時の圧は, 約 $25 \mathrm{~g} と し$, 手術時では, 局所麻酔後の手術直前に測定した。

\section{結 果}

対象症例 143 症例, 385 歯の上下顎別では, 上顎 235 歯, 下顎 150 歯, 部位別では, 上買前歯部 56 歯, 上顎小曰歯部 82 歯, 上顎大臼歯部 97 歯, 下顎前歯部 54 歯, 下顎小臼歯部 49 歯, 下顎大臼歯部 47 歯で, 上顎歯の方が圧倒的に多く, 最も多かったのは, 上顎 大臼歯部, 次に上顎小臼歯部で, 他の部位よりきわ だって多く, 両部で全体の約 $46 \%$ と半数近くを占め ていた。最も少なかったのは, 下顎大臼歯部, 次に下 顎小臼歯部で, 前歯部では, 上下顎に差がなかった。

表 1 上下䋶別部位別歯周ポケットの深さ $(\mathrm{mm})$

\begin{tabular}{c|cc|c}
\hline & 上 蕦 & 下 顎 & Total \\
\hline 前 歯 部 & $4.2 \pm 1.8$ & $3.0 \pm 1.5$ & $3.6 \pm 1.8$ \\
小臼歯部 & $3.6 \pm 1.5$ & $3.3 \pm 1.7$ & $3.5 \pm 1.9$ \\
大臼歯部 & $4.0 \pm 2.2$ & $4.1 \pm 2.0$ & $4.0 \pm 2.2$ \\
\hline Total & $3.9 \pm 2.0$ & $3.5 \pm 1.8$ & $3.8 \pm 2.0$ \\
\hline
\end{tabular}

対象患者における手術前プラーク付着状態は, O'Leary らのプラーク・コントロール・レコード2)で, $20.4 \%$ であり, 手術前の歯肉出血指数は，17.5\% で あった。

手術別では, Widman 改良法に準じたフラップ手

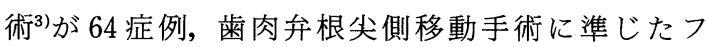
ラップ手術 ${ }^{3}$ が 65 症例とほぼ同数で, 両者で全手術 症例の約 $90 \%$ を占めていた。その他，遠心部くさび 形切除手術が 11 症例, access frap, カーテンテク ニックなどが 3 症例あった。

\section{1. 手術時の歯周ポケットの深さ}

手術時における歯周ポケットの深さは, $3.8 \pm 2.0$ $\mathrm{mm}$ であり, 上下顎別では, 上顎において深い歯周ポ ケットが存在していた。部位別では，大臼歯に深い歯 周ポケットが存在していた。これらをさらに上下顎別 にみてみると, 上顎前歯部が最も深く, 次に下顎大臼 歯部，上顎大臼歯部の順であった。下䫟前歯部は最も 浅かった（表 1 )。

1）歯面別歯周ポケットの深さ

歯面別での歯周ポケットの深さは, $\mathrm{MB}$ が $3.6 \pm$ $1.9 \mathrm{~mm}, \mathrm{~B}$ が $2.9 \pm 1.9 \mathrm{~mm}, \mathrm{DB}$ が $3.7 \pm 1.9 \mathrm{~mm}$, $\mathrm{ML}$ が $4.1 \pm 2.0 \mathrm{~mm}$, L が $3.4 \pm 1.9 \mathrm{~mm}$, DL が 4.1 $\pm 2.0 \mathrm{~mm}, \mathrm{M}$ が $4.0 \pm 1.8 \mathrm{~mm}, \mathrm{D}$ が $4.2 \pm 1.9 \mathrm{~mm}$ で近遠心中央部および舌 (口蓋) 側部でより深い歯周ポ ケットが存在し, 唇(煩)側部では浅かった。最も深 かったのは, 遠心中央部, 次に, 舌(口蓋)側の近心隅角 部，および遠心隅角部であった。最も浅かったのは, 唇 (頓) 側中央部, 次に舌 (口蓋) 側中央部であった。

上下顎別では，上顎において，下顎より深い傾向に あり, 最も深い歯面は, 上顎前歯の口蓋側近心隅角部 で $5.0 \pm 1.9 \mathrm{~mm}$, 次いで上顎大臼歯の口蓋側近心隅 角部で $4.7 \pm 2.3 \mathrm{~mm}$ および上顎大臼歯の遠心中央部 で $4.7 \pm 2.3 \mathrm{~mm}$ であった。最も浅い歯面は，下顎前 歯の唇側中央部で $1.9 \pm 1.2 \mathrm{~mm}$, 次いで下顎小臼歯 の唇側中央部で $2.2 \pm 1.5 \mathrm{~mm}$, 下顎前歯の舌側中央 部で $2.2 \pm 1.3 \mathrm{~mm}$ ，であった（表 2 )。 
表 2 歯面別歯周ポケットの深さ (mm)

\begin{tabular}{|c|c|c|c|c|c|c|c|c|}
\hline & MB & B & DB & ML & $\mathrm{L}$ & $\mathrm{DL}$ & $\mathrm{M}$ & D \\
\hline 全 & $\begin{array}{r}3.6 \\
\pm 1.9\end{array}$ & $\begin{array}{r}2.9 \\
\pm 1.9\end{array}$ & $\begin{array}{r}3.7 \\
\pm 1.9\end{array}$ & $\begin{array}{c}4.1 \\
\pm 2.0\end{array}$ & $\begin{array}{r}3.4 \\
\pm 1.9\end{array}$ & $\begin{array}{r}4.1 \\
\pm 2.0\end{array}$ & $\begin{array}{r}4.0 \\
\pm 1.8\end{array}$ & $\begin{array}{r}4.2 \\
\pm 1.9\end{array}$ \\
\hline 上顎 前 歯 & $\begin{array}{r}4.2 \\
\pm 1.8\end{array}$ & $\begin{array}{r}2.9 \\
\pm 1.4\end{array}$ & $\begin{array}{r}3.8 \\
\pm 1.5\end{array}$ & $\begin{array}{r}5.0 \\
\pm 1.9\end{array}$ & $\begin{array}{r}4.5 \\
\pm 1.8\end{array}$ & $\begin{array}{r}4.7 \\
\pm 1.7\end{array}$ & $\begin{array}{r}4.5 \\
\pm 1.6\end{array}$ & $\begin{array}{r}4.3 \\
\pm 1.6\end{array}$ \\
\hline 上顎小臼歯 & $\begin{array}{r}3.5 \\
\pm 2.1\end{array}$ & $\begin{array}{r}2.5 \\
\pm 1.7\end{array}$ & $\begin{array}{r}3.3 \\
\pm 1.8\end{array}$ & $\begin{array}{r}4.2 \\
\pm 1.9\end{array}$ & $\begin{array}{r}3.4 \\
+1.8\end{array}$ & $\begin{array}{r}4.0 \\
\pm 2.0\end{array}$ & $\begin{array}{r}3.9 \\
\pm 1.6\end{array}$ & $\begin{array}{r}4.1 \\
\pm 2.0\end{array}$ \\
\hline \multirow[t]{2}{*}{ 上顎大臼歯 } & $\begin{array}{r}3.7 \\
+2.1\end{array}$ & $\begin{array}{r}3.5 \\
\pm 2.1\end{array}$ & $\begin{array}{r}3.8 \\
\pm 2.2\end{array}$ & $\begin{array}{r}4.7 \\
\pm 2.3\end{array}$ & $\begin{array}{r}3.5 \\
+2.1\end{array}$ & $\begin{array}{r}4.2 \\
\pm 2.3\end{array}$ & $\begin{array}{r}4.4 \\
\pm 2.1\end{array}$ & $\begin{array}{r}4.7 \\
\pm 2.3\end{array}$ \\
\hline & MB & B & DB & ML & $\mathrm{L}$ & $\mathrm{DL}$ & $\mathrm{M}$ & $\mathrm{D}$ \\
\hline 下顎 前 歯 & $\begin{array}{r}3.4 \\
\pm 1.4\end{array}$ & $\begin{array}{r}1.9 \\
\pm 1.2\end{array}$ & $\begin{array}{r}3.6 \\
\pm 1.5\end{array}$ & $\begin{array}{r}2.9 \\
\pm 1.3\end{array}$ & $\begin{array}{r}2.2 \\
\pm 1.3\end{array}$ & $\begin{array}{r}3.4 \\
\pm 1.4\end{array}$ & $\begin{array}{r}3.1 \\
\pm 1.5\end{array}$ & $\begin{array}{r}3.8 \\
\pm 1.7\end{array}$ \\
\hline 下顎小臼歯 & $\begin{array}{r}3.0 \\
\pm 1.1\end{array}$ & $\begin{array}{r}2.2 \\
\pm 1.5\end{array}$ & $\begin{array}{r}3.4 \\
\pm 1.6\end{array}$ & $\begin{array}{r}3.5 \\
\pm 1.7\end{array}$ & $\begin{array}{r}3.2 \\
\pm 2.0\end{array}$ & $\begin{array}{r}4.2 \\
\pm 2.0\end{array}$ & $\begin{array}{r}3.4 \\
\pm 1.5\end{array}$ & $\begin{array}{r}3.8 \\
\pm 1.6\end{array}$ \\
\hline 下顎大臼歯 & $\begin{array}{r}3.7 \\
\pm 2.1\end{array}$ & $\begin{array}{r}4.2 \\
\pm 2.2\end{array}$ & $\begin{array}{r}4.4 \\
\pm 2.3\end{array}$ & $\begin{array}{r}3.9 \\
\pm 1.9\end{array}$ & $\begin{array}{r}3.6 \\
\pm 1.8\end{array}$ & $\begin{array}{r}4.1 \\
\pm 2.1\end{array}$ & $\begin{array}{r}4.2 \\
\pm 1.8\end{array}$ & $\begin{array}{r}4.2 \\
\pm 1.7\end{array}$ \\
\hline
\end{tabular}

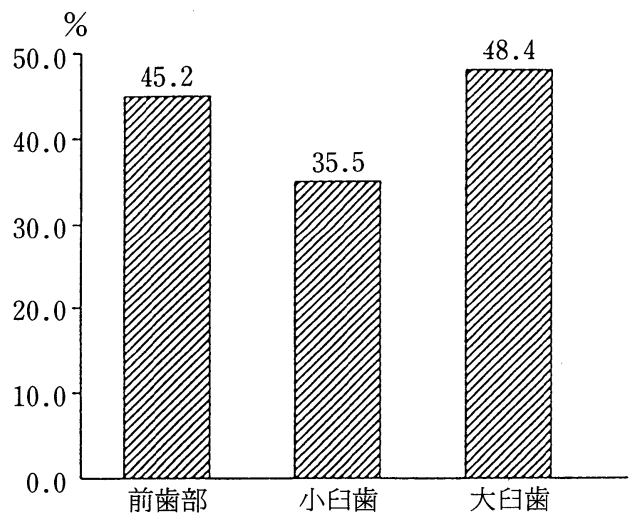

図 $54 \mathrm{~mm}$ 以上の歯周ポケット率（部位別）

\section{2） $4 \mathrm{~mm}$ 以上の歯周ポケット率}

手術対象部位の中には, 手術を必要としないとされ る $4 \mathrm{~mm}$ 未満の部位も含まれることがあるので，それ らの中で $4 \mathrm{~mm}$ 以上の歯周ポケットを有している部位 のみを抽出し, 検討してみた。

$4 \mathrm{~mm}$ 以上の歯周ポケットを有する割合は, 大臼歯 部が最も多く $48.4 \%$, 次が前歯部で $45.2 \%$, 最後は 小臼歯部で $35.5 \%$ であった（図 5 )。歯面別では, MB が $36.6 \%, \mathrm{~B}$ が $24.7 \%$, BD が $42.3 \%, \mathrm{ML}$ が $50.4 \%, \mathrm{~L}$ が $34.5 \%$, DL が $52.7 \%, \mathrm{M}$ が $50.1 \%$, $\mathrm{D}$ が $53.3 \%$ で, 遠心中央部で最も多く, 次に舌(口蓋) 側遠心隅角部, 舌 (口蓋) 側近心隅角部であった(図 6 )。

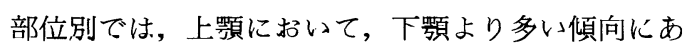

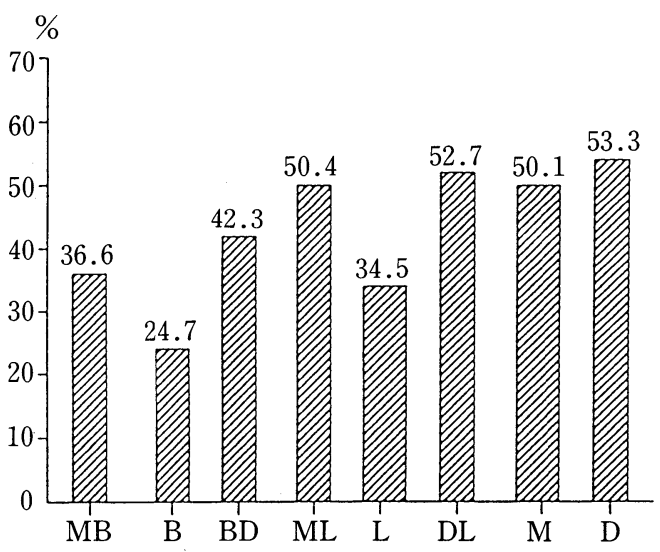

図 $64 \mathrm{~mm}$ 以上の歯周ポケット率（歯面別)

り, 最も多かったのは，上頡前歯口蓋側近心隅角部 で, $71.4 \%$ であり, 次いで上顎前歯口蓋側の遠心隅 角部で $70.9 \%$, 次に上顎前歯部近心中央部で $67.9 \%$ であった（表 3 )。

\section{2. 手術後 6 カ月の歯周ポケットの深さ}

手術時対象 143 症例の中から, 手術後 6 力月の 40 症例 118 歯を手術後 6 力月の研究対象とした。プラー ク付着状態は, 平均 $23.2 \%$ で, 手術時の值よりわず かに上昇していた。歯肉出血指数は, 平均 $10.2 \%$ で 手術時に比べると大幅に減少していた。平均歯周ポ ケットの深さは $2.0 \pm 1.0 \mathrm{~mm}$ で, 手術時のほほ半分

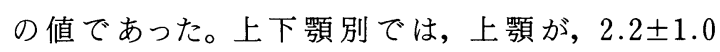
$\mathrm{mm}$, 下㖽が $1.7 \pm 1.0 \mathrm{~mm}$ で上顎でやや深い傾向に 
表 3 歯面別 $4 \mathrm{~mm}$ 以上の歯周ポケット率（\%)

\begin{tabular}{|c|c|c|c|c|c|c|c|c|}
\hline & MB & B & DB & ML & $\mathrm{L}$ & DL & M & D \\
\hline 上䫟 前歯 部 & 48.2 & 23.2 & 42.8 & 71.4 & 59.0 & 70.9 & 67.9 & 60.7 \\
\hline 上顎小臼歯部 & 30.5 & 14.7 & 29.7 & 51.2 & 34.2 & 48.8 & 43.9 & 51.2 \\
\hline 上顎大臼歯部 & 34.0 & 31.9 & 43.3 & 60.8 & 31.9 & 51.5 & 58.7 & 59.8 \\
\hline & MB & B & DB & ML & $\mathrm{L}$ & $\mathrm{DL}$ & M & D \\
\hline 下頻前歯部 & 46.3 & 11.1 & 53.8 & 24.1 & 13.0 & 46.3 & 20.0 & 44.5 \\
\hline 下䫟小臼歯部 & 22.4 & 14.2 & 32.6 & 36.7 & 28.6 & 48.0 & 36.7 & 38.8 \\
\hline 下䫟大臼歯部 & 34.0 & 31.9 & 43.3 & 60.8 & 31.9 & 51.5 & 58.7 & 59.8 \\
\hline
\end{tabular}

表 4 上下䪽別部位別歯周ポケッ トの深さ (手術後 6 力月)

\begin{tabular}{|c|c|c|}
\hline \multicolumn{3}{|c|}{ 上下顎別平均歯周ポケットの深さ } \\
\hline 上 & 顎 & $2.2 \pm 1.0 \mathrm{~mm}$ \\
\hline 下 & 顎 & $1.7 \pm 1.0 \mathrm{~mm}$ \\
\hline \multicolumn{3}{|c|}{ 部位別平均歯周ポケットの深さ } \\
\hline & 歯 & $2.0 \pm 1.0 \mathrm{~mm}$ \\
\hline 小帠 & 歯 & $1.9 \pm 1.0 \mathrm{~mm}$ \\
\hline 大臼 & 歯 & $2.2 \pm 1.0 \mathrm{~mm}$ \\
\hline
\end{tabular}

表 5 手術後 6 力月の改善状態

\begin{tabular}{ccc}
\hline 手術時 & 平均改善値 $(\mathrm{mm})$ & $3 \mathrm{~mm}$ 以下改善率* \\
\hline $4 \sim 6 \mathrm{~mm}$ & $2.5 \pm 1.2$ & $94.4 \%$ \\
$7 \mathrm{~mm}$ 以上 & $4.8 \pm 1.7$ & $82.9 \%$ \\
\hline
\end{tabular}

*3 $\mathrm{mm}$ 以下改善率： 6 力月後に $3 \mathrm{~mm}$ 以下に改善 した部位の割合を示す

あった。部位別では, 前歯部が $2.0 \pm 1.0 \mathrm{~mm}$, 小臼 歯部が $1.9 \pm 1.0 \mathrm{~mm}$ ，大鼠歯部が $2.2 \pm 1.0 \mathrm{~mm}$ で大 臼歯部に深い歯周ポケットが存在していた（表 4 )。

6 力月後の平均改善値は, $1.9 \pm 1.7 \mathrm{~mm}$ で $82.6 \%$ に扔いて $1 \mathrm{~mm}$ 以上の改善を認め, 不変は, $14.2 \%$ であった。一方， $3.2 \%$ で増悪傾向を認めた（図 7 )。 手術時 4 6 mm 歯周ポケットの改善值は $2.5 \pm 1.2$ $\mathrm{mm}$ であり $94.4 \%$ が $3 \mathrm{~mm}$ 以下に推移していたのに 対し, $7 \mathrm{~mm}$ 以上の歯周ポケットの改善値は $4.8 \pm 1.7$ $\mathrm{mm}$ と高く, 手術時 $4 \sim 6 \mathrm{~mm}$ の歯周ポケットの改善 值の倍近くを示し $82.9 \%$ が $3 \mathrm{~mm}$ 以下に推移した。 すなわち, 手術時の歯周ポケットが深いほど手術後 6 カ月では高い改善傾向を示した（表 5 )。

部位別改善率では，上䪽前歯部が $90.9 \%$ と高い改 善率を示し, 次に，下䝷大臼歯部が $83.3 \%$, 下顎前 歯部が $81.6 \%$ であった。一方, 増悪率が高かったの

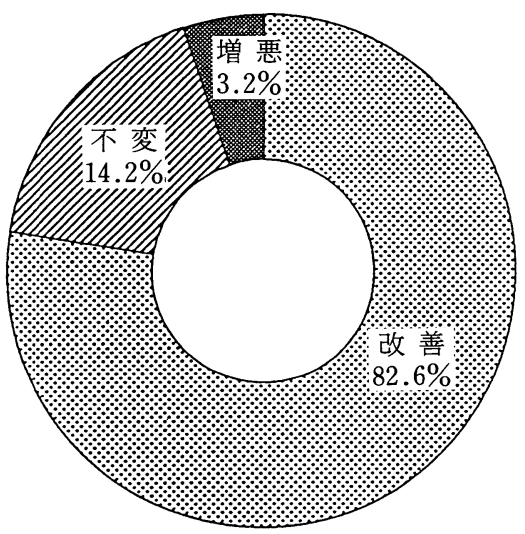

図 7 手術後 6 力月の改善率

は, 上澦大臼歯部の $5.1 \%$, 次に, 下額前歯部の $3.7 \%$ であった（表 6 )。歯面別では，唇（煩）側近 心隅角部の改善率が $94.2 \%$ と高く, 次いで遠心中央 部の $86.4 \%$ であり, 改善率が低かったのは, 唇（煩） 側中央部の $70.3 \%$ であった。一方, 増悪傾向が高 かったのは, 舌 (口蓋) 側近心隅角部と遠心隅角部で ともに $5.1 \%$ であり, 増悪傾向が少なかったのは, 唇 （煩）側近心隅角部で $0.8 \%$ であった。平均改善值は, 遠心中央部が最も高く $2.2 \pm 1.9 \mathrm{~mm}$, 次に, 舌（口 蓋) 側遠心隅角部 $2.2 \pm 1.8 \mathrm{~mm}$ で, 手術時歯周ポ ケットが深いほど改善が認められた（表 7 ）。

\section{3. 手術後 12 カ月の歯周ポケットの深さ}

手術時対象 143 症例の中から, 手術後 12 力月の 50 症例 144 歯を手術後 12 力月の研究対象とした。プ ラーク付着状態は, 平均 $27.4 \%$ で手術時さらに手術 後 6 カ月の值より上显していた。歯肉出血指数は, 平 均 $12.2 \%$ で手術時の值に比較すると減少していたが, 手術後 6 力月の值より上昇していた。平均歯周ポケッ トの深さは $2.2 \pm 1.1 \mathrm{~mm}$ で手術時の值に比べると大 幅に減少していたが, 手術後 6 力月の值より, わずか 
表 6 上下顎別部位別改善率（手術後 6 力月）（\%）

\begin{tabular}{|c|c|c|c|c|c|c|}
\hline & \multicolumn{3}{|c|}{ 上 } & \multicolumn{3}{|c|}{ 下 } \\
\hline & 前 歯 部 & 小臼歯部 & 大臼歯部 & 前 歯 部 & 小臼歯部 & 大兒歯部 \\
\hline 改 善 & 90.9 & 77.0 & 80.1 & 81.6 & 79.2 & 83.3 \\
\hline 不 変 & 6.5 & 19.5 & 14.7 & 14.7 & 17.5 & 15.8 \\
\hline 増 悪 & 2.6 & 3.5 & 5.1 & 3.7 & 3.3 & 0.8 \\
\hline
\end{tabular}

表 7 歯面別改善率 (手術後 6 力月) (\%)

\begin{tabular}{|c|c|c|c|c|c|c|c|c|c|}
\hline & & MB & B & DB & ML & $\mathrm{L}$ & DL & $\mathrm{M}$ & D \\
\hline 改 & 善 & 94.2 & 70.3 & 83.9 & 85.6 & 78.8 & 85.6 & 78.0 & 86.4 \\
\hline 不 & 変 & 6.8 & 26.3 & 12.7 & 9.3 & 18.6 & 9.3 & 19.5 & 11.0 \\
\hline 増 & 悪 & 0.8 & 3.4 & 3.4 & 5.1 & 2.5 & 5.1 & 2.5 & 2.5 \\
\hline & & $\begin{array}{r}1.9 \\
+1.6\end{array}$ & $\begin{array}{r}1.4 \\
+1.6\end{array}$ & $\begin{array}{r}1.9 \\
\pm 1.6\end{array}$ & $\begin{array}{r}2.1 \\
\pm 1.8\end{array}$ & $\begin{array}{r}1.8 \\
\pm 1.6\end{array}$ & $\begin{array}{r}2.2 \\
\pm 1.8\end{array}$ & $\begin{array}{r}1.9 \\
\pm 1.8\end{array}$ & $\begin{array}{r}2.2 \\
\pm 1.9\end{array}$ \\
\hline
\end{tabular}

表 8 上下䪽別部位別歯周ポケッ トの深さ (手術後 12 力月)

\begin{tabular}{|c|c|c|}
\hline \multicolumn{3}{|c|}{ 上下顎別平均歯周ポケットの深さ } \\
\hline 上 & 顎 & $2.4 \pm 1.3 \mathrm{~mm}$ \\
\hline 下 & 顎 & $2.0 \pm 1.0 \mathrm{~mm}$ \\
\hline \multicolumn{3}{|c|}{ 部位別平均歯周ポケットの深さ } \\
\hline 前 & 歯 & $2.0 \pm 0.9 \mathrm{~mm}$ \\
\hline 小 $E$ & 歯 & $2.1 \pm 1.1 \mathrm{~mm}$ \\
\hline 大 $E$ & 歯 & $2.5 \pm 1.2 \mathrm{~mm}$ \\
\hline
\end{tabular}

表 9 手術後 12 力月の改善状態

\begin{tabular}{ccc}
\hline 手術時 & 平均改善值 $(\mathrm{mm})$ & $3 \mathrm{~mm}$ 以下改善率* \\
\hline $4 \sim 6 \mathrm{~mm}$ & $2.1 \pm 1.3$ & $83.8 \%$ \\
$7 \mathrm{~mm}$ 以上 & $5.2 \pm 1.9$ & $81.5 \%$ \\
\hline
\end{tabular}

*3 $\mathrm{mm}$ 以下改善率 : 12 力月後に $3 \mathrm{~mm}$ 以下と なった部位の割合を示す

に上昇していた。上下顎別では上顎が， $2.4 \pm 1.3$ $\mathrm{mm}$ ，下顎が $2.0 \pm 1.0 \mathrm{~mm}$ で，上下䫟ともに深くな る傾向にあった。部位別では, 前歯部が $2.0 \pm 0.9$ $\mathrm{mm}$, 小臼歯部が $2.1 \pm 1.1 \mathrm{~mm}$, 大臼歯部が $2.5 \pm$ $1.2 \mathrm{~mm}$ で手術後 6 力月の值と比較すると前歯部で変 化なく, 小臼歯部, 大臼歯部で深くなる傾向があり, 大臼歯部が最も深く，またその傾向があった（表 8 ）。

12 力月後の平均改善值は, $1.5 \pm 1.9 \mathrm{~mm}$ で $68.2 \%$ において $1 \mathrm{~mm}$ 以上の改善を認め, 不変は $22.4 \%$ で あった。一方， $9.4 \%$ で増悪傾向を認めた。これら は, 手術後 6 力月に比べると再発傾向にあることを示 している (図 8 )。手術時, 4〜 6 $\mathrm{mm}$ の歯周ポケット

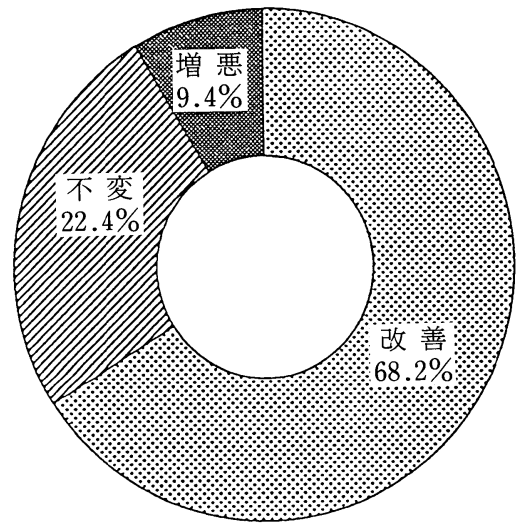

図 8 手術後 12 力月の改善率

の改善值は $2.1 \pm 1.3 \mathrm{~mm}$ であり, $83.8 \%$ が $3 \mathrm{~m}$ 以下 に推移していた。 $7 \mathrm{~mm}$ 以上の歯周ポケットの改善值 は $5.2 \pm 1.9 \mathrm{~mm}$ で $81.5 \%$ が $3 \mathrm{~mm}$ 以下に推移してい た。ともに手術後 6 力月に比べると再発傾向にあるこ とを示していた（表 9 )。

部位別改善率では，上顈前歯部が $93.7 \%$, 次に， 下䫇大鼠歯部が $85.7 \%$ でこれらはともに, 手術後 6 カ月のものに比べると高い值であった。一方, 下䪽前 歯部は $51.9 \%$ と低い值を示し, 増悪率も $15.9 \%$ と最 も高い值を示した。次に増悪率が高かったのは, 上顎 大臼歯部で $12.2 \%$ であり，他方，上顎前歯部では増 悪傾向がなかった（表 10）。歯面部では，唇（煩）側 遠心隅角部の改善率が $74.3 \%$ と高く, 次いで唇（煩） 側近心隅角部が $72.2 \%$ であった。改善率が低かった のは, 唇（頓）側中央部の $61 / 1 \%$ であった。改善率 は, 手術後 6 力月の値と比較すると低下した。一方, 
表 10 上下顎別部位別改善率（手術後 12 力月）（\%)

\begin{tabular}{|c|c|c|c|c|c|c|}
\hline & \multicolumn{3}{|c|}{ 上 } & \multicolumn{3}{|c|}{ 下 } \\
\hline & 前 歯 部 & 小臼歯部 & 大臼歯部 & 前 歯 部 & 小臼歯部 & 大臼歯部 \\
\hline 改 & 93.7 & 69.3 & 65.1 & 51.9 & 74.3 & 85.7 \\
\hline 不 変 & 6.3 & 22.8 & 22.7 & 32.2 & 21.0 & 12.5 \\
\hline 増 悪 & 0 & 8.0 & 12.2 & 15.9 & 4.8 & 1.8 \\
\hline
\end{tabular}

表 11 歯面別改善率（手術後 12 力月）（\%）

\begin{tabular}{lc|rrr|rrr|rr}
\hline & & \multicolumn{1}{|c}{$\mathrm{MB}$} & $\mathrm{B}$ & $\mathrm{DB}$ & $\mathrm{ML}$ & $\mathrm{L}$ & \multicolumn{1}{c|}{$\mathrm{DL}$} & $\mathrm{M}$ & $\mathrm{D}$ \\
\hline 改 & 善 & 72.2 & 61.1 & 74.3 & 66.7 & 70.8 & 70.8 & 61.8 & 68.1 \\
不 & 変 & 20.1 & 34.7 & 20.1 & 22.9 & 18.1 & 20.1 & 25.0 & 18.1 \\
増 & 悪 & 7.6 & 4.2 & 5.6 & 10.4 & 11.1 & 9.0 & 13.2 & 13.9 \\
\hline \multicolumn{2}{l|}{ 平 均 } & 1.6 & 1.2 & 1.6 & 1.7 & 1.5 & 1.8 & 1.4 & 1.6 \\
\multicolumn{2}{l}{ 改善値 $\mathrm{mm}$} & \pm 2.0 & \pm 1.6 & \pm 1.8 & \pm 2.2 & \pm 1.9 & \pm 2.1 & \pm 2.0 & \pm 2.0
\end{tabular}

表 12 MWFによる改善値

\begin{tabular}{c|cc}
\hline & 手術時 & 平均改善值 $(\mathrm{mm})$ \\
\hline \multirow{2}{*}{6 力月後 } & $4 \sim 6 \mathrm{~mm}$ & $2.3 \pm 1.3$ \\
& $7 \mathrm{~mm}$ 以上 & $4.1 \pm 1.8$ \\
\hline \multirow{2}{*}{12 力月後 } & $4 \sim 6 \mathrm{~mm}$ & $1.8 \pm 1.3$ \\
& $7 \mathrm{~mm}$ 以上 & $4.8 \pm 2.2$ \\
\hline
\end{tabular}

増悪傾向が高かったのは, 遠心中央部の $13.9 \%$ で, 次に近心中央部の $13.2 \%$ であり，歯間部において増 悪する傾向が明らかになった。平均改善值は舌（口 蓋）側遠心隅角部が最も高く $1.8 \pm 2.1 \mathrm{~mm}$ であり， 最も低かったのは，唇（煩）側中央部で $1.2 \pm 1.6$ $\mathrm{mm}$ であった。いずれの值も, 手術後 6 カ月の值と比 較すると低下した（表 11）。

\section{4. 手術法別による歯周ポケットの深さ}

手術法別のうち,Widman 改良法に準じたフラップ 手術 (以下, MWF と略) と歯肉弁根尖側移動手術に準 じたフラップ手術 (以下 APF と略)について, 手術後 6 力月, 12 力月の歯周ポケットの深さを検索した。

研究対象は, 手術後 6 力月の 40 症例のうち, MWF 症例は 17 例, APF 症例は 18 例, 手術後 12 力 月の 50 症例のうち, $\mathrm{MWF}$ 症例は 20 例, $\mathrm{APF}$ 症例 は 27 例である。

MWF 症例での手術後 6 カ月の歯周ポケット平均改 善值は, 手術時 $4 \sim 6 \mathrm{~mm}$ の歯周ポケットが, $2.3 \pm 1.3$ $\mathrm{mm}, 7 \mathrm{~mm}$ 以上の歯周ポケットが $4.1 \pm 1.8 \mathrm{~mm}$ と手 術時の歯周ポケットが深いほど高い改善值を示した。

手術後 12 力月では, 手術時 $4 \sim 6 \mathrm{~mm}$ の歯周ポケッ トが $1.8 \pm 1.3 \mathrm{~mm}, 7 \mathrm{~mm}$ 以上の歯周ポケットが 4.8
表 13 手術別部位別改善値

（手術時 $4 \mathrm{~mm}$ 以上の歯周ポケット） (mm)

\begin{tabular}{|c|c|c|c|c|}
\hline & & 前 歯 部 & 小臼歯部 & 大臼歯部 \\
\hline $\mathrm{M}$ & 6 力月後 & $2.1 \pm 1.5$ & $2.9 \pm 1.8$ & $2.1 \pm 1.5$ \\
\hline F & 12 力月後 & $2.7 \pm 2.3$ & $2.1 \pm 1.5$ & $1.8 \pm 1.6$ \\
\hline A & 6 力月後 & $2.9 \pm 1.3$ & $3.6 \pm 1.7$ & $4.1 \pm 2.0$ \\
\hline $\mathrm{F}$ & 12 力月後 & $2.8 \pm 1.3$ & $3.5 \pm 2.2$ & $3.5 \pm 2.1$ \\
\hline
\end{tabular}

$\pm 2.2 \mathrm{~mm}$ となり, 手術時 $4 \sim 6 \mathrm{~mm}$ の歯周ポケット では，改善值が低くなったのに対し， $7 \mathrm{~mm}$ 以上の歯 周ポケットでは, 改善值が高くなった（表 12）。部位 別では, 手術後 6 力月では, 小臼歯部が最も高く, $2.9 \pm 1.8 \mathrm{~mm}$ であり, 手術後 12 力月では, 前歯部が 高い值を示した（表 13）。歯面別では，手術後 6 力月 では, 唇（煩）側遠心隅角部で $3.0 \pm 1.3 \mathrm{~mm}$ であり, 次に, 舌 (口蓋) 側遠心隅角部で $2.9 \pm 1.4 \mathrm{~mm}$ で あった。近心中央部は $2.3 \pm 1.7 \mathrm{~mm}$ と最も低い值を 示した。手術後 12 力月では, 唇（頓）側中央部が, $2.7 \pm 1.2 \mathrm{~mm}$ と最も高い值を示した。最も低い值を 示したのは唇（煩）側近心隅角部であった（表 14）。

$\mathrm{APF}$ 症例での手術後 6 カ月の歯周ポケット平均改 善値は, 手術時 4 $6 \mathrm{~mm}$ の歯周ポケットが $2.7 \pm 1.1$ $\mathrm{mm}, 7 \mathrm{~mm}$ 以上の歯周ポケットが $5.3 \pm 1.5 \mathrm{~mm}$ で あった。手術前の歯周ポケットが深いほど高い改善值 を示したことは，MWF 症例の場合と同様であった が, MWF と比較すると手術時 4 6 $\mathrm{mm}$ の歯周ポ ケット, $7 \mathrm{~mm}$ 以上の歯周ポケット共に高い改善值を 示した。手術後 12 力月後では, 手術時 $4 \sim 6 \mathrm{~mm}$ の歯 周ポケットが $2.3 \pm 1.2 \mathrm{~mm}, 7 \mathrm{~mm}$ 以上の歯周ポケッ 
表 14 歯面別歯周ポケットの深さ（mm）

\begin{tabular}{|c|c|c|c|c|c|c|c|c|c|}
\hline & & MB & B & DB & ML & L & DL & $\mathrm{M}$ & D \\
\hline \multirow{2}{*}{$\begin{array}{l}\mathrm{M} \\
\mathrm{W} \\
\mathrm{F}\end{array}$} & 6 力月後 & $\begin{array}{r}2.5 \\
\pm 1.2\end{array}$ & $\begin{array}{r}2.8 \\
\pm 0.8\end{array}$ & $\begin{array}{r}3.0 \\
\pm 1.3\end{array}$ & $\begin{array}{r}2.5 \\
\pm 1.8\end{array}$ & $\begin{array}{r}2.7 \\
\pm 1.8\end{array}$ & $\begin{array}{r}2.9 \\
\pm 1.4\end{array}$ & $\begin{array}{r}2.3 \\
\pm 1.7\end{array}$ & $\begin{array}{r}2.8 \\
\pm 1.9\end{array}$ \\
\hline & 12 力月後 & $\begin{array}{r}1.9 \\
\pm 0.9\end{array}$ & $\begin{array}{r}2.7 \\
\pm 1.2\end{array}$ & $\begin{array}{r}2.5 \\
\pm 1.1\end{array}$ & $\begin{array}{r}2.4 \\
\pm 2.3\end{array}$ & $\begin{array}{r}2.4 \\
\pm 2.0\end{array}$ & $\begin{array}{r}2.4 \\
\pm 2.4 \\
\end{array}$ & $\begin{array}{r}2.1 \\
\pm 2.0\end{array}$ & $\begin{array}{r}2.5 \\
\pm 2.1\end{array}$ \\
\hline \multirow{2}{*}{$\begin{array}{l}\mathrm{A} \\
\mathrm{P} \\
\mathrm{F}\end{array}$} & 6 力月後 & $\begin{array}{r}3.7 \\
\pm 2.2\end{array}$ & $\begin{array}{r}3.9 \\
\pm 1.9\end{array}$ & $\begin{array}{r}3.6 \\
\pm 1.3\end{array}$ & $\begin{array}{r}3.4 \\
\pm 1.7\end{array}$ & $\begin{array}{r}3.4 \\
\pm 1.6\end{array}$ & $\begin{array}{r}3.5 \\
\pm 1.7\end{array}$ & $\begin{array}{r}3.2 \\
\pm 1.7\end{array}$ & $\begin{array}{r}3.6 \\
\pm 1.8\end{array}$ \\
\hline & 12 力月後 & $\begin{array}{r}3.9 \\
\pm 2.4\end{array}$ & $\begin{array}{r}3.4 \\
\pm 2.0\end{array}$ & $\begin{array}{r}3.5 \\
\pm 1.9\end{array}$ & $\begin{array}{r}3.5 \\
\pm 2.1\end{array}$ & $\begin{array}{r}3.6 \\
\pm 2.1\end{array}$ & $\begin{array}{r}3.4 \\
\pm 1.8\end{array}$ & $\begin{array}{r}2.9 \\
\pm 1.8\end{array}$ & $\begin{array}{r}3.0 \\
\pm 2.0\end{array}$ \\
\hline
\end{tabular}

表 15 APF による改善值

\begin{tabular}{c|cc}
\hline & 手術時の PD & 平均改善値 $(\mathrm{mm})$ \\
\hline \multirow{2}{*}{6 力月後 } & $4 \sim 6 \mathrm{~mm}$ & $2.7 \pm 1.1$ \\
& $7 \mathrm{~mm}$ 以上 & $5.3 \pm 1.5$ \\
\hline \multirow{2}{*}{12 力月後 } & $4 \sim 6 \mathrm{~mm}$ & $2.3 \pm 1.2$ \\
& $7 \mathrm{~mm}$ 以上 & $5.2 \pm 1.8$ \\
\hline
\end{tabular}

トが $5.2 \pm 1.8 \mathrm{~mm}$ となり，ともに改善值は，わずか ながら減少した（表 15）。部位別では, 手術後 6 力月 では, 大臼歯部が最も高く, $4.1 \pm 2.0 \mathrm{~mm}$ であり, 手術後 12 カ月では, 小臼歯と大臼歯部が高い值を示 した。MWF 症例と比較すると, 手術後 6 力月, 12 カ月ともに, APF 症例の方が, 高い改善值を示した (表 13)。歯面別では, 手術後 6 力月では, 唇（煩） 側中央部が $3.9 \pm 1.9 \mathrm{~mm}$ と最も高い值であり, 次に, 唇（煩）側近心隅角部で $3.7 \pm 2.2 \mathrm{~mm}$ であった。最 も低い值を示したのは近心中央部で $3.2 \pm 1.7 \mathrm{~mm}$ で あった。手術後 12 カ月では, 唇 (煩) 側近心隅角部 が, $3.9 \pm 2.4 \mathrm{~mm}$ と最も高い值を示した。最も低い 值を示したのは, 近心中央部であり, 次に遠心中央部 であった（表 14）。

\section{考 察}

最近では，歯周ポケットを除去するために手術する のではなく, 従って歯周ポケットの深さを手術適応の 指標とするべきでないという見解がある。しかし，歯周 ポケットの深さは, だれにでもわかりやすい一つの重 要な指標である。日本歯科大学新潟歯学部附属病院歯 周治療科では, 歯周ポケットの深さ $4 \mathrm{~mm}$ を手術適応 の一つの指標としている。これは, 歯肉縁下 $3 \mathrm{~mm}$ を越 える根面ではプラークとその産生物の完全除去は困難 であり，不完全な歯肉縁下のプラークコントロールを
全く行っていないに等しいとするWaerhaug の報 告 4,5$)$, また歯周ポケットが $4 \mathrm{~mm}$ を越えるといくら 臨床家が努力しても完全な歯肉縁下のプラークおよび 歯石の除去は困難であるという報告6 8)などに基づい ている。すなわち, 患者自身でプラークコントロールが でき,一方, 術者側で完全に歯石を除去することができ るのは $3 \mathrm{~mm}$ までの歯周ポケットと解䣋されるわけ で, 従って $4 \mathrm{~mm}$ 以上の歯周ポケットでは歯周外科手 術を行うかどうか検討し, 状態に応じて手術手技を選 択している。ただし,歯周ポケットの深さが $4 \mathrm{~mm}$ 以上 である場合に,必ず手術を行うというのではなく,歯肉 からの出血傾向, 歯周ポケットからの滲出液, さらに 歯肉の色, 形, 硬さなどの変化を参考にして, 個々に最 終決定を下している。すなわち, 歯周ポケットの深さが $4 \mathrm{~mm}$ 以上であることは, 他の状況を加味して手術へ の移行を検討する必要があるということである9 。

歯周ポケットの深さが $4 \mathrm{~mm}$ 以上ある場合に行われ る歯周外科手術には, 歯肉切除手術, 切除新付着手 術, フラップ手術があるが, この中で最も頻繁に行わ れているのはフラップ手術である。

そこで, フラップ手術の対象となる歯周ポケットの 深さは, どの位で, どこの部位の歯周ポケットが最も 深いのかを検索することにした。このような研究は, 他に見ることができなかったが, 歯周治療の臨床にお いては, 是非, 知っておきたい事項である。また,こ の研究においては, 歯周ポケットの診査を 8 点法で 行った。現在, 歯周ポケットの診查は個々の歯の煩側 遠心, 煩側中央, 煩側近心おょび舌側遠心, 舌側中 央, 舌側近心の 6 点を計測する 6 点法が主に行われて いる。浜口は1現在 6 点法が一般的である理由は, 歯 周疾患が部位特異性を持った疾患であるためと考えら れる。歯周組織破壊は, 1 本の歯の中でも, 部分的に さまざまな程度で進行することがある。そのため，的 
確な診断を下し，治療するためには，より細かい診査 の必要性が生じてくる。1歯に対し 6 点を診査すれ ば, おおよそ, その歯の歯周疾患の罹患状況を把握で きるであろう。しかし，ここで問題となるのが歯間部 であるとし, 歯間部における歯周組織破壊の程度を的 確に診断するために， 6 点の測定に加え, 近心部・遠 心部の隣接面コンタクトポイント直下を測定する 8 点 法を導入した。そして, 遠心中央部に最も深い歯周ポ

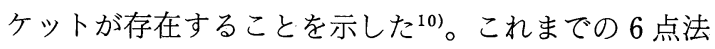
では, 測定していなかった部位に最も深い部位が存在 していたわけで，この部位を行わない 6 点法による歯 周ポケットの研究は不完全であることがわかる。

以上の理由によって, フラップ手術時の歯周ポケッ トの状態を 8 点法によって検索したが, さらに, 手術 時に存在した歯周ポケットが, 手術後 6 力月, 12 力 月ではどのように推移するのかを検索した。また，日 本歯科大学新潟歯学部附属病院歯周治療科では, 歯肉 と歯根面との付着によって歯周ポケットをなくす目的 では Widman改良法に準じたフラップ手術を，フ ラップを移動することによって歯周ポケットをなくす 目的では歯肉弁根尖側移動手術に準じたフラップ手術 を行っているが3), それらの手術手技によって, 手術 後の歯周ポケットの深さはどのように変化していくの かについても検索した。

\section{1. 手術時の歯周ポケットの深さ}

手術時における歯周ポケットの梁さは, 上頡におい て下顎より梁く, 部位別では大兒歯部が最も深く小臼 歯部が最も浅かった。これを上下效別にみてみると上 顎前歯部が最も深く, 次に, 下顎の大白歯, 上頡の大 臼歯の順であった。下顎の前歯部は最も浅かった。

上顎において下顎より歯周ポケットが深いことは, 歯周疾患患者の初診時の診查においても同様にみら れ, 和田 ${ }^{11}$ は, 102 名の歯周疾患患者を対象とした 初診時の歯周ポケットの深さにおいて, 上下顎間では やや上薠が深く, 左右間でもほとんど差がみられな かったと述べている。また, 大臼歯部で深く, 小臼歯 部で浅いことについて渡辺ら ${ }^{12}$ は, 歯周疾患を主訴と して来院した患者の初診時の歯周ポケットの深さが 4 $\mathrm{mm}$ 以上を有する歯の割合は, 大臼歯に高く, 小臼歯 に低い傾向を示したと述べ，プラークコントロールの 困難性が理由として考えられると記している。

歯面別では, 近遠心中央部で最も歯周ポケットが深 く, 次に舌 (口蓋) 側部であり, 唇 (煩) 側部では最 も浅かった。最も深かったのは, 遠心中央部で, この
部位は 8 点法で測定しなければわからない部位であ り, 歯周ポケットを 8 点法で測定することの重要性を 知ることができる。上下顎別では，上顎において，下 顎より深い傾向にあり,一方，唇（煩）側と舌（口 蓋）側の比較では，舌（口蓋）側においてょり深いこ とは前述の通りである。このことは, 和田ら ${ }^{11}$ の初診 時の喰査に扔ける結果と同様で，和田ら ${ }^{11)}$ は上䪽にお いてその程度が顕著であるのは, 咬合とか食片の流れ などの外傷性因子や解剖的因子が下顎の舌側よりも上 䪽の口蓋側に組織破壊を起こしやすいことによる可能 性があげられると述べている。最も深い歯面は上䋶前 歯の口蓋側近心隅角部であるが, 上澦前歯口蓋側は, いずれの部位も深く,この部位には，特異的な歯周組 織破壊因子が存在していることが伺い知れる。一方, 上顎大臼歯の遠心中央部が次に深いが, これは, 最後 臼歯の遠心部であり, 強い咬合力に加えて, プラーク コントロールの困難さが，歯周組織破壊を促進してい るものと思われる。

$4 \mathrm{~mm}$ 以上の歯周ポケットを有している部位, 換言 すれば, 純粋に手術を必要とする部位のみについてみ てみると大臼歯が最も多く, 次に前歯で, 小臼歯は最 も少なかった。歯面別では遠心中央部が最も多く，大 臼歯の遠心部では手術の対象となる歯周ポケットが最 も多く, 従って, 手術の頻度も高いことを知ることが できる。また, 唇 (煩) 側, 舌 (口蓋) 側ともに中央 部は, 手術の対象となる歯周ポケットが少なく, 他 方，歯間部において手術を必要とすることがわかる。

部位別では, 上顎前歯口蓋側, また, 上下顎大臼歯 舌（口蓋）側近心隅角部および上下澦大臼歯遠心部に おいて手術を必要とする部のあることがわかる。

\section{2. 手術後 6 カ月の歯周ポケットの深さ}

手術時 $3.8 \pm 2.0 \mathrm{~mm}$ であった歯周ポケットの深さ は, 手術後 6 力月では $2.0 \pm 1.0 \mathrm{~mm}$ と減少した。 Lindhe $ら^{13)}$ は初診時の診查で $4.2 \pm 0.2 \mathrm{~mm}$ だった歯 周ポケットが, 手術後 6 カ月では, $2.4 \pm 0.1 \mathrm{~mm}$ に なったことを記している。手術時と初診診查時という ことで最初の基準值が異なり,また, 手術内容も Widman 改良法だけということで異なるが参考にな る数值であり, 今回の研究結果にも近似性のあること がわかる。

上下顎別では, 上顎が, 下顎より深い傾向を示した が, 手術時においても, 上顎は深く, この結果とも思 われる。部位別では, 大臼歯部で深く, 次に前歯部, 小臼歯部であったが，この傾向は手術時におけるもの 
と同様で，手術によって部位特異的に変化することは なかった。全般的には，82.6\%で $1 \mathrm{~mm}$ 以上の改善 をみたが,一方， $3.2 \%$ では，増悪傾向を示した。手 術前歯周ポケットの深さと改善率との関係をみるた め, 4〜 6 $\mathrm{mm}$ のいわゆる中等度進行症例と $7 \mathrm{~mm}$ 以 上の高度進行症例を比較したところ, 高度進行症例の 方が歯周ポケットの改善状態は強く, 歯周ポケットは 深いほど手術後改善状態は良いことがわかった。一 方， 6 力月後に $3 \mathrm{~mm}$ 以下に改善した割合をみてみる と中等度進行症例の方が高く, 手術前歯周ポケットが 深いと手術によって改善される值は大きくても，3 $\mathrm{mm}$ 以下に改善される率は低下することがわかった。 部位別改善率では, 上顎前歯部が最も高く, 一方, 増悪率では，上顎大臼歯部が最も高かった。これは， 上顎前歯の手術は, 術野の確保, 器具の到達が容易 で，手術が完全に行えるのに対し，上顎大臼歯部では 術野の確保, 器具の到達が思うようにまかせず手術も 不完全に終わる傾向にあることを示している。歯面別 にみてみると唇 (煩) 側近心隅角部の改善率が最も高 く, この部は, 術野の確保また器具の到達ともに容易 であり,一方, 増悪率が高かったのは舌（口蓋）側近 心隅角部と遠心隅角部で, この部の手術は慎重に行う 必要のあることを示している。平均改善率は遠心中央 部が最も高く,これは, 手術時歯周ポケットが深いほど 改善があることを示しているが,一方, 手術の困難な遠 心部においても完全に処置されていることがわかる。

\section{3. 手術後 12 カ月の歯周ポケットの深さ}

手術時 $3.8 \pm 2.0 \mathrm{~mm}$ であった歯周ポケットの深さ は, 手術後 6 力月では $2.0 \pm 1.0 \mathrm{~mm}$ となり, 手術後 12 力月では $2.2 \pm 1.1 \mathrm{~mm}$ とわずかに上昇した。Lindhe ら ${ }^{13}$ は, 初診時の診查で $4.2 \pm 0.2 \mathrm{~mm}$ だった歯 周ポケットが, 手術後 6 力月では $2.4 \pm 0.1 \mathrm{~mm}$ にな り, 手術後 12 カ月では $2.5 \pm 0.1 \mathrm{~mm}$ と上昇したこと を記している。診查時期, 手術内容は異なるがわれわ れの結果も同様の傾向を示し, 日時の経過と共に, 歯 周ポケットは再び深くなる傾向のあることがわかる。 手術を完璧に行って歯周ポケットがない状態にし, そ れ以後の定期的なメインテナンスによって，再発しな いようにするのが歯周治療の原則であるが，現実は手 術が不完全に終わる場合もあり，メインテナンス間隔 また処置内容も理想通りには行えないことが少なくな い。これらの結果の重積によってやがて歯周ポケット は再び深くなる傾向を示すことになり, 再発という事 態を迎えるが，これらの結果はそれら再発までの一経
過を示しているといえる。手術後 6 力月と比較すると 下顎の方が，また大臼歯の方が歯周ポケットは深くな る傾向があった。前歯においては, 全く変化がなかっ た。 12 力月後における改善率は $68.2 \%$ で，6 カ月の ものが $82.6 \%$ であったのに比較すると明らかに再発 傾向にあることを示している。増悪傾向も $9.4 \%$ で 6 カ月に扔るものの約 3 倍であった。

部位別改善率では, 上顎前歯部において最も高いこ とは変りないが, 増悪率では下顎前歯部が最も高くな り, 手術後 6 力月とは異なった傾向を示した。歯面別 にみてみると近心中央部および遠心中央部において増 悪率が高くなり，また舌（口蓋）側ではどの部位も増 悪率が高く, 再発傾向は, 近遠心中央部また舌（口 蓋）側に発現する傾向のあることがわかる。近遠心中 央部における歯周ポケットの変化は，これまで検討さ れていなかったが, 今回の研究によって, 手術後 12 力月の再発傾向は近遠心中央部にあることが明らかに なった。ここにも, 歯周ポケットの測定を 8 点法で行 うことの意義がある。

\section{4. 手術法別による歯周ポケットの深さ}

われわれの科では手術前の歯周ポケットの深さ，ま た，手術部位などにより，MWF と APF を選択して おり，このため，ぞちらの手術法を選択するべきであ るという結論は得られないが,一応二者の間での歯周 ポケットの深さを検討してみた。総じて, APFの方 がMWFょり歯周ポケットの平均改善值は高く, $\mathrm{APF}$ によってょり歯周ポケットは消失していくこと が示された。しかし，MWFでは，12 カ月後になる と中等度進行症例において, 平均改善值が低下し, 一 方, 高度進行症例においては上昇した。すなわち, 浅 い歯周ポケットより深い歯周ポケットにおいてより改 善が保たれることがわかった。また，APFにおいて は 12 力月後になると中等度進行度症例, 高度進行症 例ともに平均改善値は，6力月後におけるより低く なった。すなわち, 歯周ポケットの深さにかかわら ず，歯周ポケットの改善は減少することがわかった。

手術時 $4 \mathrm{~mm}$ 以上の歯周ポケットについて部位別に みてみると MWF の前歯部においては, 12 力月の改 善值が上昇し, 上澦前歯部では, MWF の結果が良好 であることを示している。歯面別では, APFの唇 (頓) 側近心部, 舌 (口蓋) 側近心部, 舌 (口蓋) 側 中央部において, 改善值が上昇し,これらの歯面で は，APF の結果が良好であることを示している。 


\section{結論}

日本歯科大学新潟歯学部附属病院歯周治療科におい て, 平成 2 年 1 月から 12 月までの 1 年間にフラップ 手術を受けた 143 症例 385 歯, 3080 歯面を研究対象 とし,さらにこの中から, 手術後 6 力月の 40 症例, 12 力月の 50 症例を追跡対象とし, 手術時, 手術後 6 力月, 手術後 12 力月の歯周ポケットの変化を近遠心 中央部を加えた 8 点法によって検索した結果，以下の 結論を得た。

\section{1. 手術時の歯周ポケットの深さ}

手術時における歯周ポケットの深さは, $3.8 \pm 2.0$ $\mathrm{mm}$ であり，上顎において，また大臼歯部において深 い歯周ポケットが存在していた。

歯面別では,近遠心中央部および舌(口蓋)側部で深 い歯周ポケットが存在し,唇(煩)側部では浅かった。

$4 \mathrm{~mm}$ 以上の歯周ポケットを有する割合は,大臼歯 部が最も多く,歯面別では遠心中央部で最も多かった。

\section{2. 手術後 6 カ月の歯周ポケットの深さ}

平均歯周ポケットの深さは $2.0 \pm 1.0 \mathrm{~mm}$ で手術時 のほぼ半分の值であり，上顎において，また大臼歯部 において深い歯周ポケットが存在していた。

6 力月後の平均改善值は $1.9 \pm 1.0 \mathrm{~mm}$ で $82.6 \%$ に おいて $1 \mathrm{~mm}$ 以上の改善をみた。そして，手術時の歯 周ポケットが深いほど手術後 6 力月では高い改善傾向 を示した。

歯面別では，唇（煩）側近心隅角部の改善率が最も 高かった。一方，増悪傾向が高かったのは，舌（口 蓋）側近心隅角部と遠心隅角部であった。

\section{3. 手術後 12 カ月の歯周ポケットの深さ}

平均歯周ポケットの深さは, $2.2 \pm 1.1 \mathrm{~mm}$ で手術 後 6 力月の值より上昇した。

12 力月の平均改善值は, $1.5 \pm 1.9 \mathrm{~mm}$ で $68.2 \%$ に おいて $1 \mathrm{~mm}$ 以上の改善をみ，手術後 6 力月に比べる と再発傾向にあった。増悪傾向が高かったのは, 遠心 中央部, 次いで, 近心中央部で, 歯間部において増悪 する傾向が明らかになった。

\section{4. 手術法別による歯周ポケットの深さ}

Widman 改良法に準じたフラップ手術と歯肉弁根
尖側移動手術に準じたフラップ手術では, 手術後 6 力 月, 12 力月ともに歯肉弁根尖側移動手術に準じたフ ラップ手術症例の方が，高い改善値を示した。

\section{文献}

1）浜口茂雄：歯間部歯周ポケットとその測定法に関す る研究. 日歯周誌, 31:608-632, 1989.

2) O'Leary, T.J. Drake, R.B. and Naylor, J.E. : The plaque control record. J. periodontol., $43: 38$, 1972

3）長谷川明：臨床歯周外科学. クインテッセンス出 版, 東京, 1987, 70-75, 75-77.

4) Waerhaug, J: Subgingival plaque and loss of attachment in periodontosis as evaluated on extracted teeth. J. Periodontol., 48:125-130, 1977.

5) Waerhaug, J:Healing of the dentoepithelial junction following subgingival plaque control. J. Periodontol., 49 : 119-134, 1978.

6) Badersten, A., Nilveus, R. and Engelberg, J : Effect of nonsurgical periodontal therapy. I Moderately advanced periodontitis. J. Clin. Periodontol. $8: 57-72,1981$.

7) HIll, R.W., Ramfjord, S.P., Morrison, E.C. Appleberry E.A., Caffesse, R.G., Kerry. G.J. and Nissle, R.R. : Four types of periodontal treatment compared over two years. J. Periodontol, $52: 655-662,1981$.

8) Pihlstrom B.L., Ortiz-Campos, C. and McHugh, R.B. : A randomized four-year study of periodontal therapy. J. Periodontol, 52:227-242, 1981.

9）長谷川明：歯周治療における外科治療の役割. 鴨井 久一，緑下プラークの抑制法，クインテッセンス出 版，東京, 1991, 173-174.

10）浜口茂雄：Probimg Depth. 歯科ジャーナル，31： 47-53, 1990.

11）和田 甫，柳澤高道，石川俊明，国富照子，本田公 亮，吉田 済：当科における歯周疾患患者の実態 第 1 報 初診時における臨床所見について。 日歯周 誌, $28 ： 863-870,1986$.

12）渡辺嘉一，林 英昭，松田文英，沼部幸博，浜田 哲, 鴨井久一：歯周疾患に関する疫学的調査（第 2 報)。日歯周誌, $25 ： 582-593,1983$.

13) Lindhe, J., Westfelt, E., Nyman, S., Socransky, S. S., Heijl, L. and Brattall, G. : Healing following surgical/non-surgical treatment of periodontal disease. J. Clin. Periodontol., 9 : 115-128, 1982.

連絡先：

日本歯科大学新潟歯学部歯周治療学教室

干 951 新潟市浜浦町 1-8 